\title{
Does organizational level capabilities is important to sustainability performance? A case study on Village Owned Enterprises in Indonesia
}

\author{
D Junita ${ }^{1}$, R N Sari ${ }^{1 *}$, R Zenita $^{1}$, Kamaliah ${ }^{1}$ \\ ${ }^{1}$ Department of Accounting, Faculty of Economics and Business, Universitas Riau, Kampus Bina \\ Widya, Km. 12.5 Simpang Baru, Panam, Pekanbaru, 28293, Indonesia \\ *ria.nellysari@lecturer.unri.ac.id
}

\begin{abstract}
This study aims to examine the effect of organizational 1 vel ca abilities (organizational capabilities, marketing capabilities and technical ca abili les) on sustainability performance. Data was obtained through questionn is distrib.ed to 121 directors of Village Owned Enterprises. Data was analyzed by sinc structural equation model-partial least square (SEM-PLS). Results showed that organ. atio al capability has a significant effect on sustainability performance. $\mathrm{Tb}$ findings also indicate that marketing capabilities and technical capabilities aiso ave a positive effect on sustainability performance. This study suggest that the optima ization of organizational capabilities are important to ensure the existence 1 the organization in the business.
\end{abstract}

Keywords: Village owned enterprises, organizat nal level capabilities, sustainability performance

\section{Introduction}

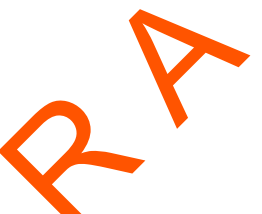

Village Owned Enterpri in Indonesian term call Badan Usaha Milik Desa or BUMDes) is a business entity established ith the aim of improving the economy and welfare of the village. At the beginn $\mathrm{ng}$ of its establishment, Village Owned Enterprises received financial support from local a d village governments. In the course of its business, Village Owned Enterprises still contin $/ 0$ get injections of funds from villages and local governments (Kemendesa, o.io). This condition cannot take place continuously. Village Owned Enterprises must be inde aent and not depend on injection of funds. For this reason, Village Owned Enterprises mus not only increase their income so that they can provide additional income to the village, but also provide benefits to the community in order to carry out its social mission.

Sustainability performance shows the ability of an organization to exist over time, protect the organization, the environment and the social life of stakeholders and the community. To improve sustainability performance, Village Owned Enterprises must have a competitive advantage. Competitive advantage will arise because of the renewal and development of its capabilities [1].

Capability is the ability of an organization to carry out its tasks or activities in a coordinated manner so as to achieve organizational goals [2, 3, 4]. Capabilities can be seen from various points of view, including organizational level capabilities [5-9]. Organizational level capabilities focus on three important orientations (a) managing an efficient and effective production department that is open to product and process innovation, (b) developing technical knowledge and expertise with regard to economies of scale, and (c) investing in equipment 